\title{
Assessment of Ancient Fridges: A Sustainable Method to Storage Ice in Hot-Arid Climates
}

\author{
M. Mahdavinejad ${ }^{1} \&$ Kavan Javanrudi ${ }^{1}$ \\ ${ }^{1}$ Department of Architecture, Art and Architecture faculty, Tarbiat Modares University, Tehran, Iran \\ Correspondence: M. Mahdavinejad, Department of architecture, Art and Architecture faculty, Tarbiat Modares \\ University, Tehran, Iran. Tel: 98-21-8288ロ37ロ9. E-mail: Mahdavinejad@modares.ac.ir
}

Received: December 26, 2011 Accepted: March 7, 2012 Online Published: July 1, 2012

doi:10.5539/ach.v4n2p133

URL: http://dx.doi.org/10.5539/ach.v4n2p133

\begin{abstract}
This article is an attempt to introducing ancient fridges as sustainable method to store ice in hot-arid Climates. Architectural heritages are considered as fundamental issue in the life of contemporaryworld.Hence, researches around this category despite of historical interest attractscientific scopesto providesustainable society through tourism industry and green architecture. In this paper among different Iranian heritage buildings, ancient fridges, or Pachal (in Persian), has been analyzed. Because of great importance of water and especially cold water in hot-arid climates, Hundreds of Pachals have built in central plateau of Iran. The interpretive technique has been applied to assessment ancient fridges. In addition, observation as a part of the authors' field work, and Historical documentsconcerning the traditional buildings built techniques and the architectural heritage of the Iraniantraditional fridges, are another part of this research. This article is atry to indicate that vernacular architecture of "Pachals" are very responsible monuments to fit the hard-life situation of hot-arid climates in ancient world.
\end{abstract}

Keywords: ancient fridges, pachal, vernacular architecture, historical heritages

\section{Introduction}

Ancient fridges are a pit with a sophisticated method to store ice in hot-arid climates. Ice prepared in winter season and reserves until hot seasons to keep meat, fruits and dairies, and also used as a method to making water cold and tasty. Considering a large hot-arid region in Iran and long summer season with high degree warmth, these buildings had a major role in providing comfort for human. Matthews (1987) comment that Chinese reserve ice thousands years before Christ, Greeks and romans makes their potables icy with stored snow, and finally in 18 century noble Europeans interested in icy potable, but storing ice method in Iran was such sophisticated that poor people also reached these facilities (p. 91). With such perspective, this article is an attempt to introducing ancient fridges in Iran.

Unfortunately there is not historical record about fridges until Safavid period. Tourists through the times had recorded several itineraries about these fridges. Sharden comments that "storing ice in Safavid era especially in Kashan city (in Isfahan province) was usual tradition" (Yaghmaei, 1995, p. 271). Also Brouin (1693) pictured a fridge in Qum city that is one of the oldest one that is destroyed today. The content of this article relies heavily on two bases: The interpretive technique has applied to assessment ancient fridges. Also observation as a part of the authors` field work, and historic documents concerning the traditional buildings built techniques and the architectural heritage of the Iranian traditional fridges, are another part of this research Here in, the architecture of Iranian ancient fridges are analyzed with respect to the following factors: The architectural background of fridges in each hot-arid regions, Construction methods and materials, and Formation of the plans and sections.

\section{Methods}

\subsection{Ancient Fridges Main Parts}

Fridges consists of several parts, here in, three major part of this building inclusive shade wall, ice cavity and ice storage, Entrance space is described. Shade Wall which is a high (up to ten meters) and lengthy (5 to 12 meters) wall has been built from East to west. Sometimes despite of main wall, other walls will be built. Also thickness 
of Shade Wall decreases from bottom to overhead of it (Figure 1, 2, 3). Ice Cavities were rectangular shaped pits which are built parallelism to Shade Wall with less length regard to it and 40 to 50 centimeters depth in ground. The role of Ice Cavity was making ice in cold winter nights. Ice Storages were a store with six meter depth which kept ice from solar radiation and raining, with roof covering (Bahadori, 1978, p. 1976).

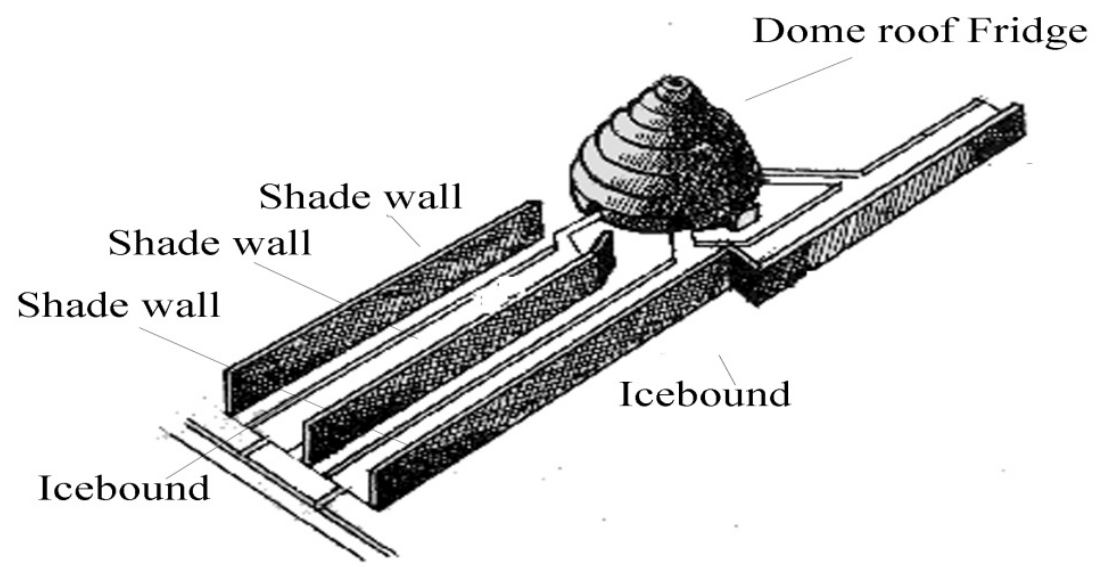

Figure 1. Ancient fridges main parts

Source: Image Archive of Tarbiat Modares University

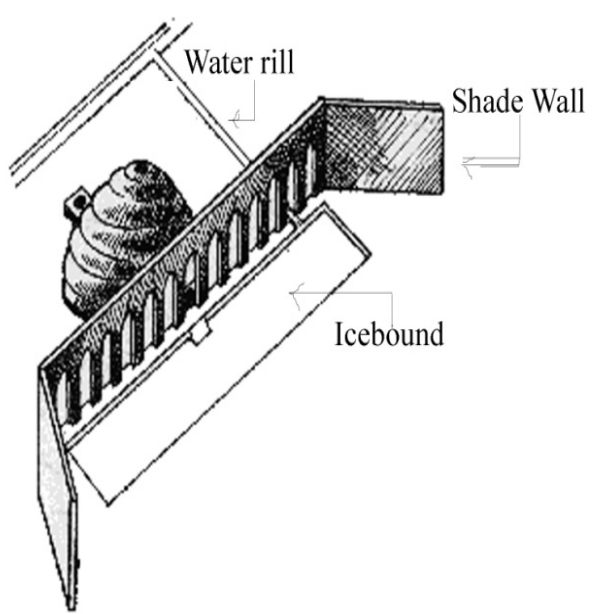

Figure 2. Ancient fridges main parts

Source: Image Archive of Tarbiat Modares University

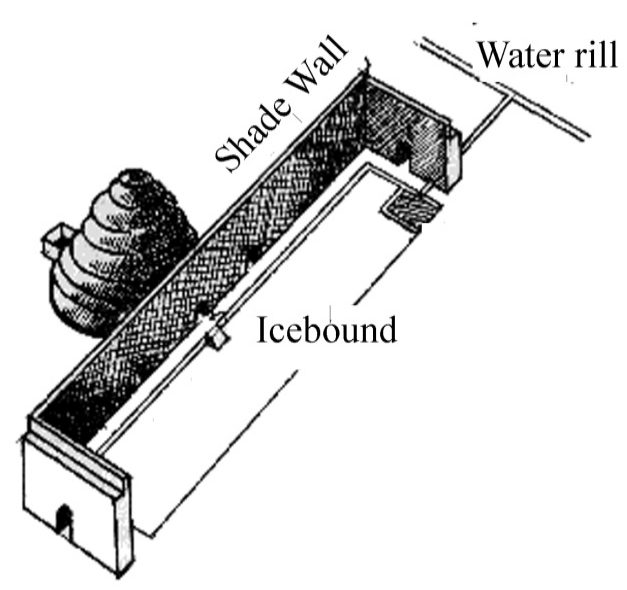

Figure 3. Ancient fridges main parts

Source: Archive of Tarbiat Modares University

\subsection{Natural Ice Making Method}

Utilization climatic aspects to create suitable environmental situation is primal element of traditional architecture of Iran. For making ice, first people dig shallow pounds with square dimensions with 40 to 50 centimeters depth which called basin (Tash-taki in Persian). Then they filled these shallow pounds with water in cold winter nights, and the day after it they divide ice huge pieces to little pieces as possible and transfer these pieces to fridge near the cavity and in each layer of pieces they spread water to increase density of ice pieces. The range of frizzing depends on weather degree and sky's condition. After about eight days and nights process of production will be stopped with an usual tradition ceremony. The last step is covering the ice with straws and brushwood and closing the fridge's entrance with sea sedge, which called Bi-Zur in Persian. Also in summers opening the entrance of fridge with another ceremony will be held (Ghobadian, 2007, p. 102).

Fridges are natural way for making Ice. To figure out the ice making process the following explanations are presented. If we have a piece of ice in shallow pounds with a determined height, and some water with a Diameter equal to "s", following relationships can be expressed to determine the size of ice making production (Figure4), 
which Eq one is for cooling water up to freezing point. Also Eq2 shows an equation for freezing water in zero degree water's layer:

Eq 1:

$$
\left(\mathrm{Q}_{\mathrm{r} 1}+\mathrm{Q}_{\mathrm{e} 1}+\mathrm{Q}_{\mathrm{c} 1}-\mathrm{Q}_{\mathrm{s} 1}\right) \Delta \mathrm{t}_{1=} \rho_{\mathrm{w}^{*}} \mathrm{~A}_{\mathrm{s}^{*}} \mathrm{C}_{\mathrm{w}} \mathrm{t}_{\mathrm{wi}}
$$

Eq 2:

$$
\left(\mathrm{Q}_{\mathrm{r} 2}+\mathrm{Q}_{\mathrm{e} 2}+\mathrm{Q}_{\mathrm{c} 2}-\mathrm{Q}_{\mathrm{s} 2}\right) \Delta \mathrm{t}_{2}=\rho_{\mathrm{w}^{*}} \mathrm{~A}_{\mathrm{s}} * \mathrm{~h}_{\mathrm{if}}
$$

Which the parameters are: (Bahadori, 1987, p. 54)

$\mathrm{Q}_{\mathrm{r} 1}$ transitive heat of radiation

$\mathrm{Q}_{\mathrm{e} 1}$ transitive heat of evaporation

$\mathrm{Q}_{\mathrm{cl}}$ transitive heat of convection

$\mathrm{Q}_{\mathrm{s} 1}$ transitive heat of water above ice surface

$\Delta \mathrm{t}_{1}$ Time to cooling the water from $\mathrm{t}_{\mathrm{wi}}$ to zero

$\Delta \mathrm{t}_{2}$ Time to freezing the water

$\rho_{\mathrm{w}}$ Density of water

$\mathrm{A}_{\mathrm{s}} \quad$ Area of ice surface in cavity

$\mathrm{h}_{\mathrm{if}}$ Freezing enthalpy

$t_{\mathrm{wi}}$

Primal temperature of the water

$\mathrm{C}_{\mathrm{w}}$ Specific Heat of water

So the ice making size would be calculated from Eq3

$\mathrm{S}^{\prime}=\rho_{\mathrm{w}} *_{\mathrm{s}} \rho_{\mathrm{i}^{*}} \Delta_{\mathrm{t}}$

$\Delta_{\mathrm{t}}=\Delta_{\mathrm{t} 1}+\Delta_{\mathrm{t} 2}$

The size of ice making at specific temperature, moisture and transitive heat coefficient is shown in Figure 10.

FI

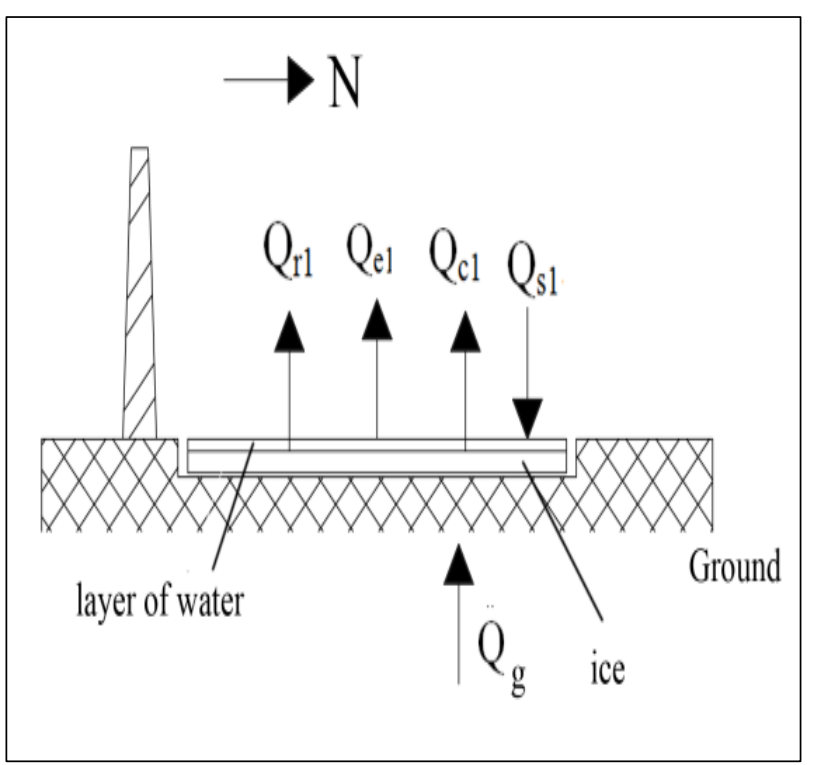

Figure 4. Section of cavity of ice making

(Yaghubi, 2010, p. 715)

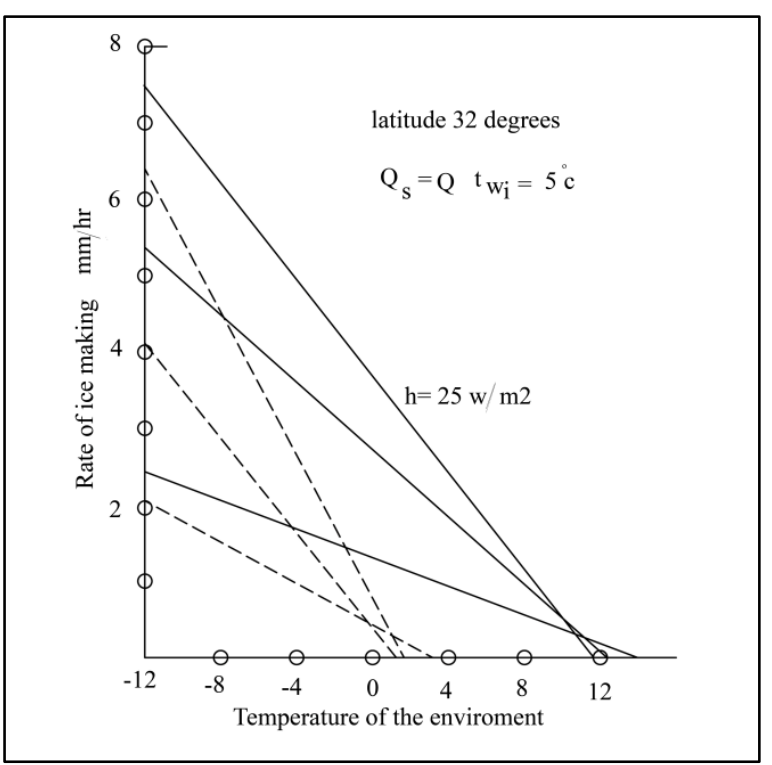

Figure 10. Rate of ice making in natural fridges (Yaghubi, 2010, p. 717)

\section{Investigating Ancient Fridge's Typology}

Architecture of fridges shows the intelligent methods had been used for insulating and preparing enough cold to reserving ice. Because of large land usage of fridges and expensive land price in cities, these buildings had been built in countryside. Fridges have three main types: domed roof fridges, underground fridges and pool fridges. 


\subsection{Domed Roof Fridges}

Domed Roof Fridges are built in margins of central dessert and eastern north of Iran (Figure5). This fridge consists of a huge conical pit. In bottom of the pit, there was a water path to lead the extra water to the shaft.

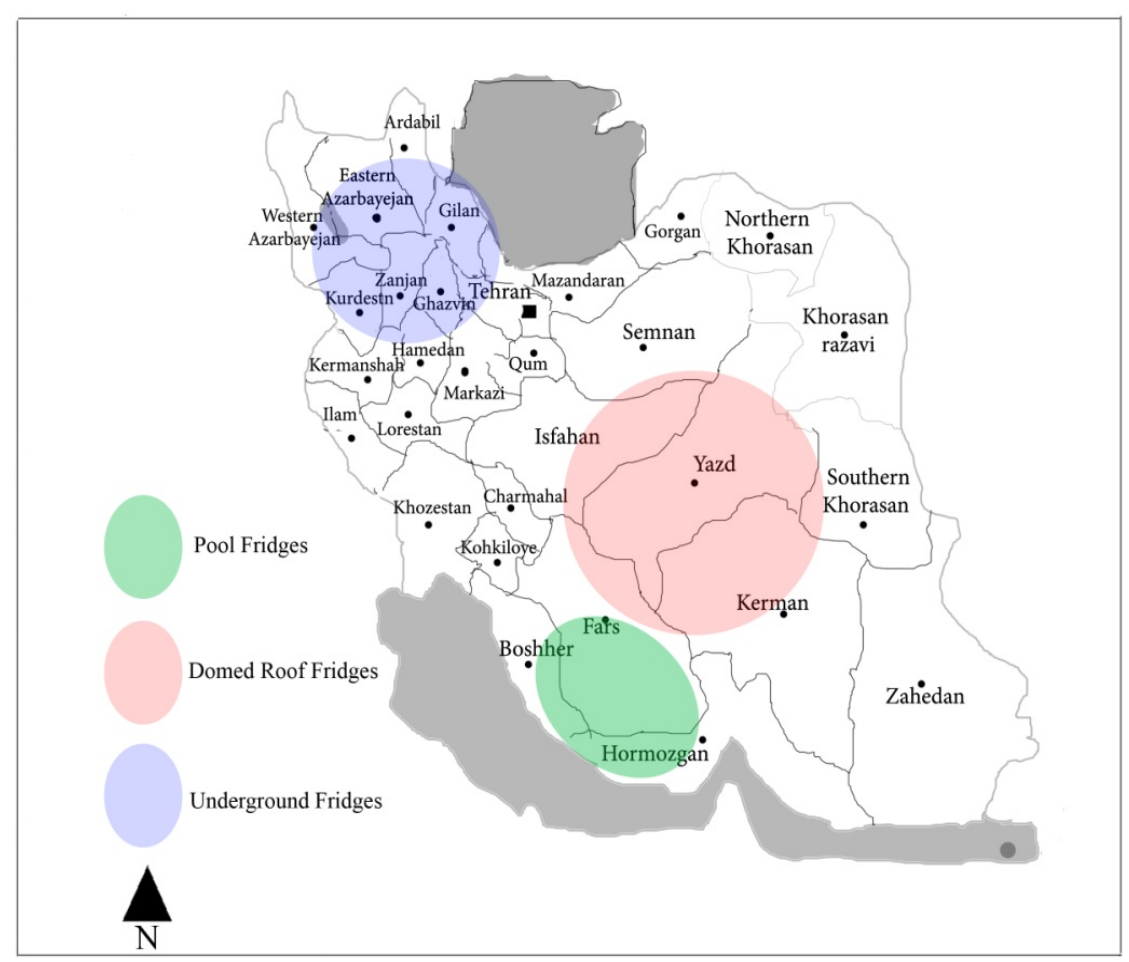

Figure 5. Location of different types of ancient fridges

The dimensions of pits were different. For example, diagonal of Meybud Pachal in Kerman is 13 meters and 6 meters depth (Figure 6). Doomed Roof Fridges has a stage and after it fridge has a squatty doom shell. Fridges dome was dowr-chin kind and the main materials are adobe and brick. Thickness of the dome decrease from bottom to overhead of it for structural and thriftily reason to reducing material usage.

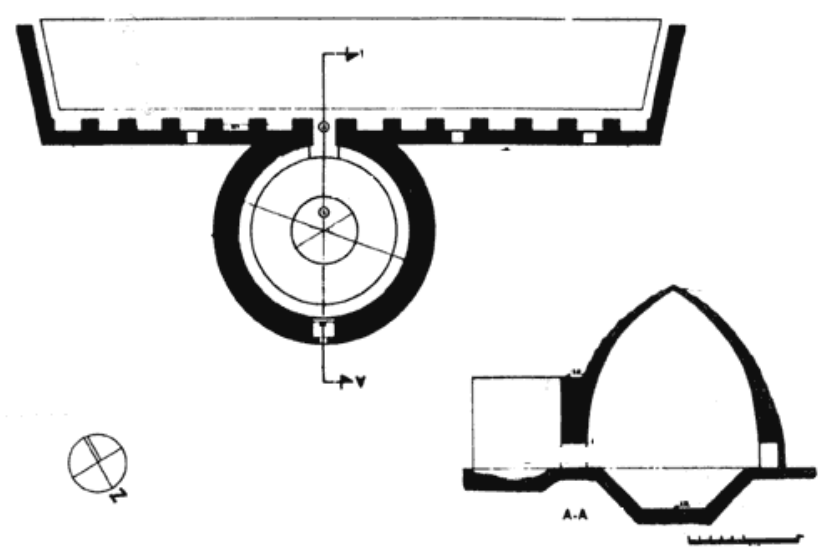

Figure 6. Different domed roof fridges in Iran (Ghobadian, 2007)

Yearly layering new adobes for reparation of dome from rain and solar radiation damages, and Echelon form of dome is for easing of this reparation. Usually a high wall has built in the northern side of the dome to provide direct south solar radiation. Fridges had 2 enteral doors, one in south side for taking ice from icebound to pit, and north side door which end to a long stairs to approaching ice pieces (Figure 7). The height of domes for climatically reasons was tall, like Meybud Pachal with 15 meters height. 

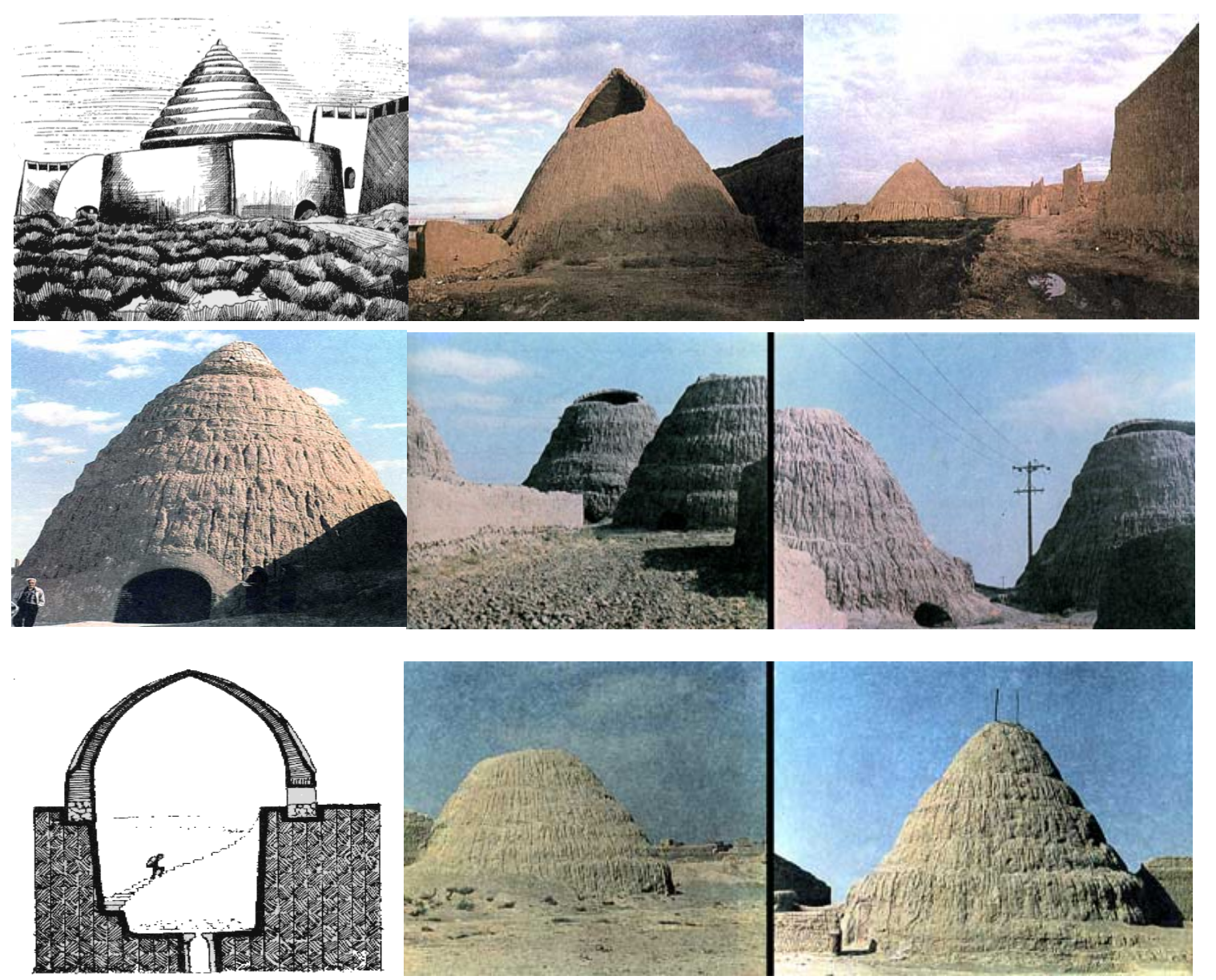

Figure 7. Different domed roof fridges in Iran

Source: Archive of Tarbiat Modares University

\subsection{Underground Fridges}

Underground Fridges were built in north and western north of Iran (Figure 5). Stone and bricks are main material of these fridges. In addition, this building has vaulted or arched roof. After frizzing ices in pit to fridge and after each layer of ice they spread ice to cohere it. Because of enough coldness of these regions, isolating the fridge was easier. Fridge has a door ending stairs to delivering ice to people. The Sa-ve Pachal in Markazi province and eastern north of Sa-ve city is one of the eminent cases of these kinds of fridges. Sa-ve Pachal height is five meters from ground surface and 3.5 meters width and 12 length. Thickness of wall is 80 centimeter and brick's dimension is 25 in 25 centimeter (Figure 8).
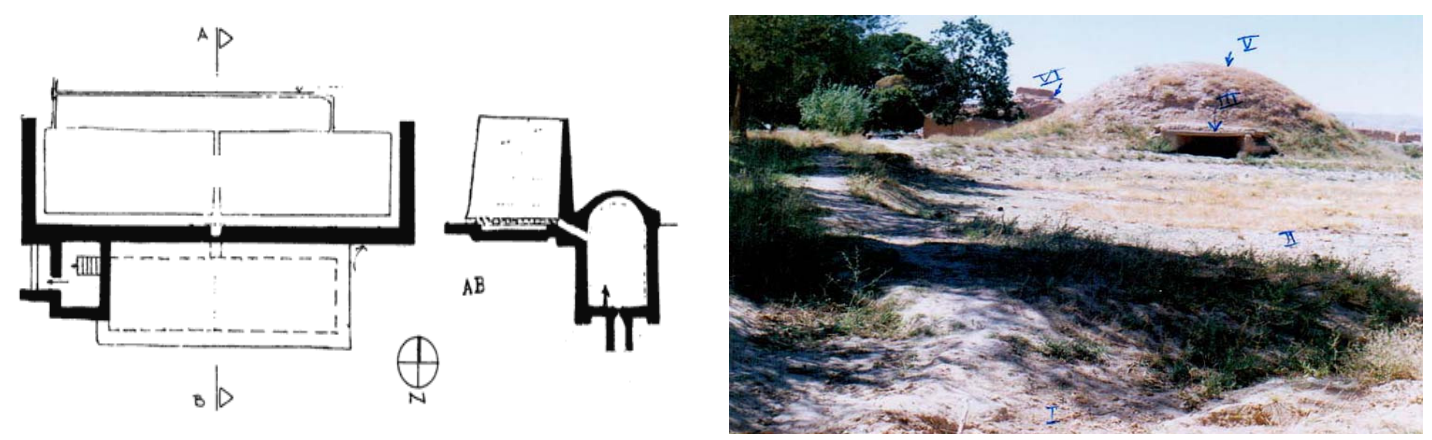

Figure 8. Different domed roof fridges in Iran (Ghobadian, 2007, p. 135) 


\subsection{Pool Fridges}

Pool Fridge is another kind of fridges had built in southern provinces of Iran. These fridges consist of a pool with five to six meters depth, 12 meters length and five meters width and a wall in north side of the pool with four to five meters height and to 12 meters length. Like another fridges making ice was in cold winter night to use it in hot summer days. After filling, the pool had been covered with straws and brushwood. Unfortunately this kind of fridges is completely destroyed today (Figure 9).

Thus, we can categorize ancient fridges to three main types. First, and more extant one, is dome roof fridges, which are located in central part of Iran. Second, is underground fridges, which are located in western and northern part of Iran. At last, pool fridges, which founded in southern part of Iran (Table1).

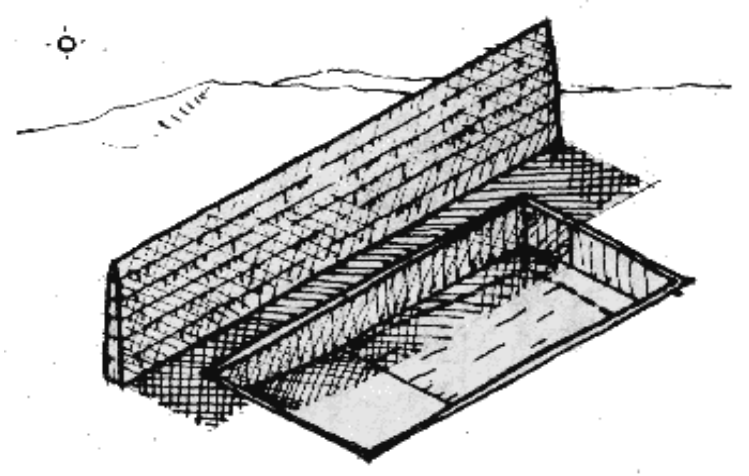

Figure 9. Different Pool Fridges in Iran (Ghobadian, 2007, p 138)

Table 1. Typology of ancient fridges

$\begin{array}{ccc}\text { Typology } & \text { Domed Roof Fridges } \\ \text { General forms } \\ \text { Location } \\ \text { Kerman, Isfahan, Yazd, } \\ \text { Mashhad, Sabzivar and etc. Tehran, Zanjan, Tabriz and } \\ \text { etc. }\end{array}$

\section{Results and Conclusions}

Until the second half of the 20th century, ancient fridges were a dominant way to keep nutrition from mildewing and have cool water for human comfort in hot seasons in Iran. Therefore, intelligent local architects by compatibly to climate constructed different types of fridges. Nowadays ancient fridge lost its importance for 
some reasons such as development in technology, fast urbanization, and changes in living styles in Iran. However, structures built for fridges still beautify the landscape and create a fairy tale atmosphere at their regions. They are valuable components of Iranian vernacular architecture. Architecture of fridges shows the intelligent methods had used for insulating and preparing enough cold to reserving ice. As a result, this survey has established a basis for valuing these monuments. They are not only historically important, but due to their elegant profiles and the harmony of their internal spaces, could considered as tourist attractions in Iran.

\section{References}

Bahadori, M. N., \& Janati, T. P. (1983). Natural production of ice in shallow pounds, Solar World Congress. International Solar Energy Society (Vol. 1, pp. 51-56). Perth, Australia.

Bahadori, M. N., \& kosari, A. (1978). Performance of Natural ice makers. Proc. of International Solar Energy Society Congress (Vol. 3, pp. 1976-1978). New Delhi, India.

Diolafava, M. J. (1990). Itinerary of Madam Diolafava.

Ghobadian, V. (2007). Climatic Assessment of Traditional Architecture of Iran. Tehran University publications.

Mahmood, Y., \& Mahdi, B. N. (2010). Ventilation and Natural Cooling Systems In Iranian Traditional Architecture. Center of collegiate Publications, Tehran, Iran.

Office of Educational programming of Fani-Herfei. (2009). Introducing of Iranian Architecture (Vol. 492.6).

Samuel, W. M. (1987). Editorial. National Geographic, 171(1), 92.

Sharden, S. J. (1995). Itinerary of Sharden (Vol. 2, pp. 270-272), Iranian publications. 